\title{
Raising Financial Reporting Standard and the Financial Stability for Banks: A Case of Commercial Banks in Sierra Leone
}

\author{
Article by Peter M Kamara \\ $P h D$ in Management, Texila American University \\ E-mail: pkamara@texilaconnect.com
}

\begin{abstract}
This article looks at two broad-spectrum of financial management discipline; the first one examines the financial stability of commercial banks by analysing their published financial statement to test their stability in the market place before the Ebola scourge. This paper focus on the Sierra Leone Company's Act 2009 and relevant Sections of the Banking Acts of Sierra Leone to analysis its alignment with the reporting standards of its financial statement produced by various firms in compliance with the IFRS standards. This report tests the financial stability of seven commercial banks in Sierra Leone with the major financial ratios used, especially the zscore analysis that check the financial stress of a firm.
\end{abstract}

Keywords: Profitability, Liquidity, Stress test, Financial Performance, Return on Capital Employed, Z-Scores, and financial statement analysis.

\section{Introduction}

The research critically evaluates the performance of financial institutions in Sierra Leone that published their accounts with a focused on the banking sectors. The research findings assess the performance output of seven banks in Sierra Leone before the Ebola scourge in West Africa. The Ebola plague started in the first quarter of 2014. Hence, the research work was based on mainly, 2013, published financial performance. The reason for this study is to test and analyse whether the banks in Sierra Leone were already in a stressed financial position before the financial meltdown, which was coursed by the deadly scourge. Hence, this report will serve as a benchmark for sector analysis and can be used to decide on an investment opportunity in such areas. As the theme for the e-conference is "Global Education, Research and Technology for Sustainable Development", it is imperative prudent to research on the financial sector to test their stress level and puffer solution for growth, thus, pave the way for sustainable development in our global society.

In this article, there are various financial analyses; stress test and advisory for institutional growth, which, were revealed for, fund managers, financial accountants, finance managers, executives, directors and investors.

- Profitability analysis

- Investing Activities

- Liquidity Issues Across Retail Banks

- Consumer and corporate lending

- Stress Test using Altman's Model

- Return on Capital Employed

\section{Methodology}

Seven banks published financial statements for 2013 were reviewed and analysed. The seven banks are Guaranty Trust Bank (GTB), FiBank (FIB), Union Trust Bank (UTB), Eco Bank (ECO), United Bank for Africa (UBA), Skye Bank and Standard Chartered Bank (SCB). Scholarly articles about the research work were the reference. 
DOI: $10.21522 /$ TIJMG.2015.03.02.Art019

ISSN: $2520-310 \mathrm{X}$

\section{Profitability analysis of the banks}

The 2013 published financial statement for commercial banks in Sierra Leone was quite impressive. Guaranty Trust Bank (GTB) came out tops regarding profitability and total assets base, recording $32 \%$ of the total profits published by the seven commercial banks under review. United Bank for Africa (UBA) and Standard Chartered Bank (SCB) were the 2nd and 3rd most profitable recording $18 \% 1$ and $17 \% 1$ respectively of the total profits of the seven banks.

Ecobank (ECO) recorded $16 \%$ of the total profit. ECO is gradually proving to be on of the fastest growing financial institution since it came into operation in Sierra Leone in 2016. Based on the seven banks' financial statements, ECO bank would have been the highest profitable bank in 2013, had its cost of capital (interest paid) been lower than that of GTB or SCB and if it had experienced a reduction in its expenses (Tulsian, 2014).

Union Trust Bank (UTB) recorded 11\% of the total profit of the banks. Most of its income, however, came from loans and advances. The bank's management should consider diversifying some of its assets to reduce its trading risks. UTB is one of the local banks that have maintained remarkable stability regarding market competitiveness, considering that its resources are locally generated.

First International Bank (FIBank), which recorded 5\% of the total profits of the seven banks under review, has demonstrated some strength in becoming a big player in the financial market, provided that the bank considers widening the trading of its assets in diverse operations.

Although FIBank recorded a significant interest income, its capital costs, however, appeared to be on the high side and it could be interesting to see if the bank's capital cost could be lowered it decided to source cheaper capital (reducing deposit interest) for its trading or revise its interest paid polices.

If FIBank's cost of capital had been lower compared to that of UTB, it would have been in a better position to take UTB's place as the 3rd best performing bank in Sierra Leone.

Skye Bank recorded $1 \%$ of the total profits. The bank had the largest share capital among the seven banks under review but does not seem to have deployed back its entire equity in its operations, but has instead held huge cash in hand. It is advisable that the bank considered utilising its share capital into several trading activities such as forex trading, loans and advances and inter-bank trading, this could significantly increase their profitability.

All seven commercial banks could have generated huge profits had they been able to lower their expenses further (Vintila, G., and Nenu, E., A., 2016). The lack of adequate electricity supply to these banks, high inflation rate and the expensive running costs, has contributed to their massive expenses. For a majority of the working day, the banks carry out their banking operation running on generators. Their enormous costs can be lowered with adequate power supply in place

An increase in the total local market of products and services will reduce the need for import of goods and services from abroad, thus creating a cheaper and more stable market environment. 


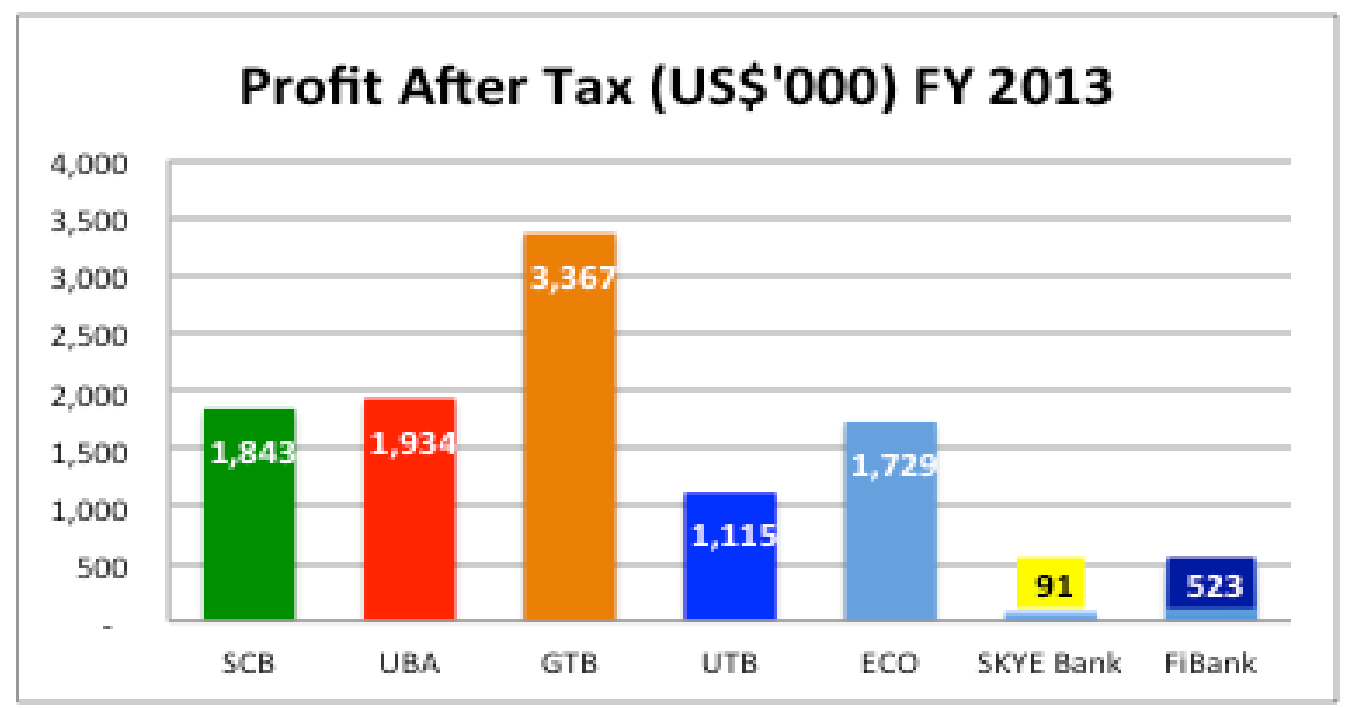

Chart 1. Profit after tax figures for retail banks in sierra leone FY 2013

On 29th May 2014, the House of Parliament in Sierra Leone unanimously approved a power purchase agreement between Copperbelt Energy Corporation Plc and the Government of Sierra Leone, to supply $128 \mathrm{MW}$ of electricity to the national Power Authority for national-wide distribution, hence adding to the national grid on the power supply. This will help reduce the huge expenses and create a competitive market for the banks in Sierra Leone (Venkatesan, T., and Nagarajan, S., K., (2012).

GTB, UTB, ECO and FIBank have all reported impairment loses. These banks should work on their credit lending policies and ensure that their loans and advances portfolios are well mitigated and risk-adjusted to avoid the short and long-term unexpected shocks. The Sierra Leone Stock Exchange (SLSE) was commissioned in 2009, providing a marketplace for the trading of equities, commodities, bonds, forex and derivatives. The banks should start participating within it to generate more investment capital and maximise their profit generation, rather than only focusing on granting loans and advances in the short-term, which might erode their total investment capital.

\section{Investing activities for the period under review}

Out of the seven banks under review, FIBank tops the investment trading over it assets, recording an impressive rate of investment. The bank has spread its assets, recording $36 \%$ on riskfree trading (T-Bills), 31\% of risk assets trading (advances to customers), 15\% of another trading (such as forex) and 18\% cash in hand. It may be useful for the bank to reduce some of it risktrading activities and focus some more of its assets into forex and securities trading. 


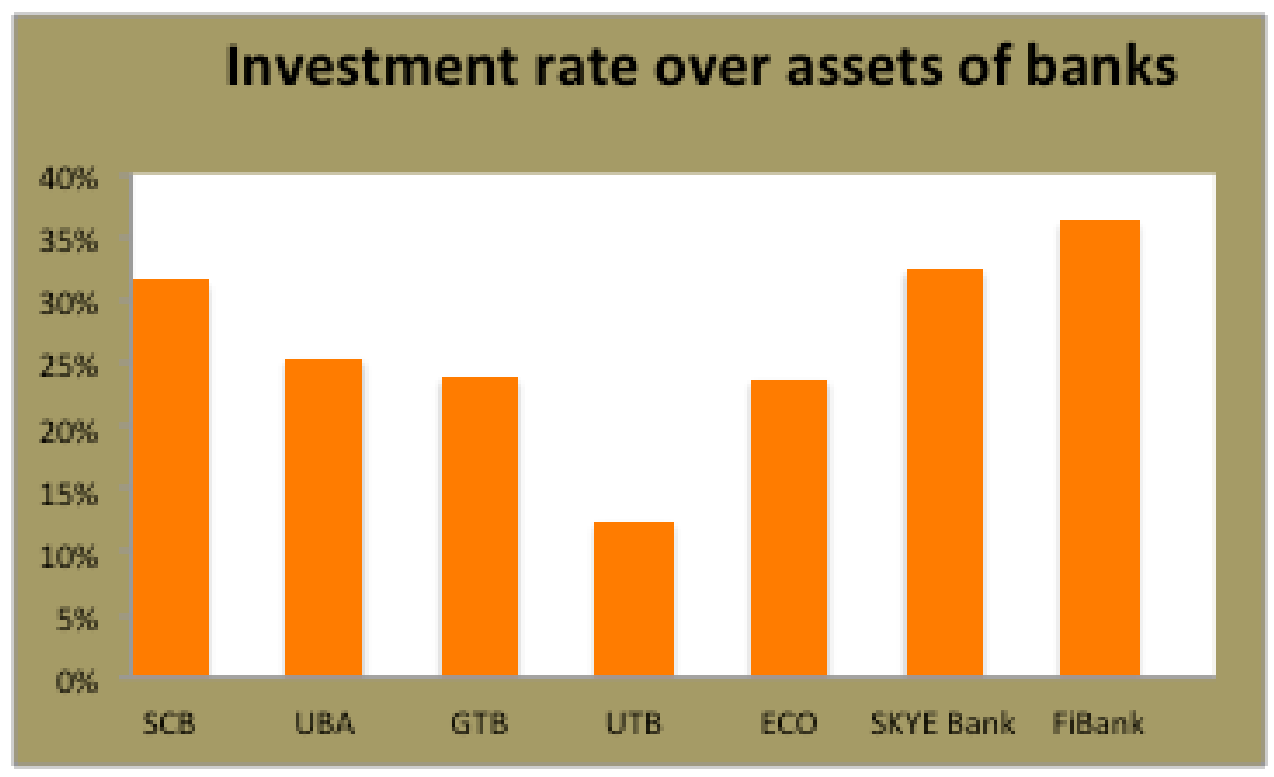

Chart 2. Investment trading over assets

SCB has spread its total assets recording $32 \%$ on risk-free training, the lending rate of $14 \%$ of total assets, forex and securities trading off 5\% and 49\% cash in hand. The bank is well managed regarding liquidity and its distribution of resources. Its cash holdings, however, are too high and the bank should consider participating in other trading activities like increasing its forex and securities trading and even somewhat increasing its lending rate. UBA and GTB invested in TBills and other investments that are risk-free at a rate of $25 \%$ and $24 \%$ respectively against its total asset base. UBA should, however, try to participate in the economic development in Sierra Leone by slightly increasing its risk assets portfolio, as SME's are the most important players to the jump-start of any economy. The bank should consider expanding its loans and advances portfolio. Its $2 \%$ lending rate of total assets indicates that they are not necessarily a leading financial institution. UBA closed up its books for 2013 with $69 \%$ cash in hand against its total assets. If this surplus cash in hand were invested, UBA would have triumphed over GTB in profit generation. The bank was able to manage its expenses quite well given this hyperinflation economy. UTB has the lowest risk-free investment activities recorded at $12 \%$ of its total assets; it is recommended that the bank reduce its risk assets trading and invest more in T-Bill and Bonds. Although the bank was able to produce huge profits from its trading, it should keep a close watch on its recorded liquidity position.

Ecobank appears to be a well-managed bank as it is thoroughly involved in both lending and investments in T-Bills and other risk-free investments. The bank seems to benefit from its Group Advisory, and it is well integrated with the economic development of Sierra Leone. Ecobank has positioned itself to be the future driver of income generation and liquidity stability for commercial banks in Sierra Leone.

\section{Liquidity issues across retail banks}

The financial sector in Sierra Leone operates on a short-term basis on both its lending and investments. The treasury bills issued by the bank of Sierra Leone are also short-term, therefore creating short-term market operations. It is prudent to analyse the various bank's liquidity on the short-term to test their stability in the market among the seven published financial statements of banks in Sierra Leone, and it is clear that SCB, UBA and Skye Bank have relatively sound liquidity positions to meet short-term demand. GTB, UTB and FIBank and Eco recorded positive profits for the year 2013. However, their liquidity reserves were negative. Hence, there is the need for these banks to focus on managing their cash positions to avoid short and long-term shocks (Sthapit, A., \& Maharjan, G. 2012). 


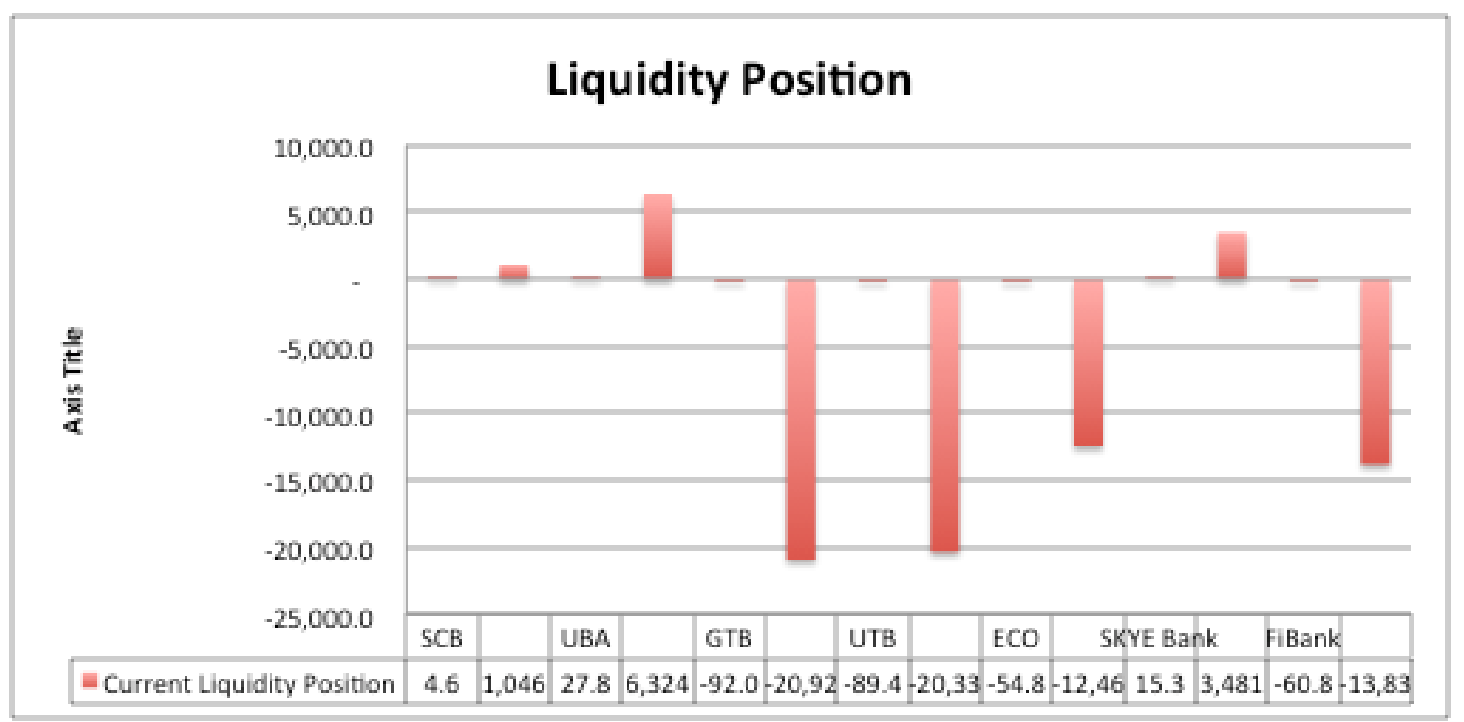

Chart 3. Liquidity position for retail banks in sierra leone based on 2013 financial statements

The regulatory authorities should ensure that banks maintain a sound liquidity position at all times, by introducing policies that will strengthen banks internal controls on liquidity. Another measure the Central Bank of Sierra Leone could add the increase of the tenure (period) of the TBills and bonds to at least five years and above to match the banks' liabilities with long-term TBills and Bonds, ultimately creating stability in the market. This will encourage the commercial banks to lend on the long-term, which will in-turn create enormous economic benefits to the nation's development. An example is the agribusinesses cannot survive in this current short-term market, as agriculture loans are more ideal on the long-term basis. If you give a farmer a loan for a short-term (let's say six months to a year), the farmer will use almost half of the loan period to prepare the soil before planting, and a further length of time will elapse before harvesting. More time will also lapse before the farmer can sell his or her produce. Eventually, the farmer will end up using all his profits paying off interests on the loan, therefore making the whole business nonprofitable. A long-term financial market needs to be launched by the Central Bank of Sierra Leone. By introducing long-term bonds, which will inspire the commercial banks to match up their risk assets with risk-free investment activities.

\section{Consumer and corporate lending}

Out of the seven banks under review, it is evident that Union Trust Bank is the highest lending financial institution in Sierra Leone with over $46 \%$ of its total assets in risk assets. This type of trading seems too risky, as the bank has exposed itself to an impairment loss of almost USD1.6million. It is advisable for the bank to expand its portfolio on forex trading, participate in the Sierra Leone Stock Exchange, etc., rather than merely trading on short-term loans and advances. The banks should reduce it risk assets to a minimal rate to diminish the risks of unexpected shocks especially when trading in the short-term. Guaranty Trust Bank also posted $29 \%$ lending rate against it total assets; it was evident that the bank bridges its lending rate advances to customers, which was over $25 \%$ of the net worth of the bank. GTB generated most of its income on its loan. However, the bank should trade carefully to create a balance between its liquidity position and revenue generated.

Ecobank recorded $22 \%$ lending rate against it total assets, which in theory means the bank was able to operate within its credit limit. However, the bank needs to focus on the management of its liquidity and balance it with profitability to avoid facing any short-term threats or shocks. UBA traded cautiously on loan and advances, and it recorded a meagre lending rate of $2 \%$. It can be deduced from the financial statements that the bank benefited from clean forex trading and low spending on administrative costs. 


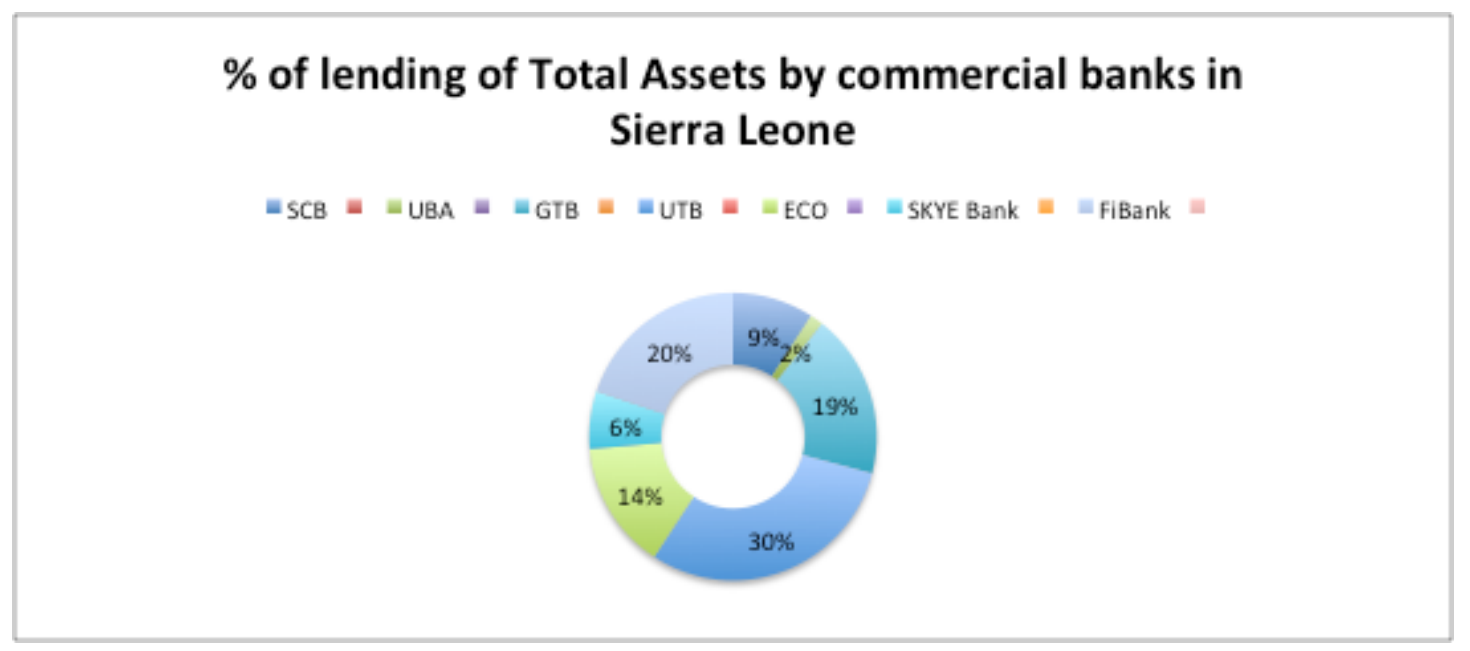

Chart 4. Lending percentage against total assets for retail banks in sierra leone fy 2013

UBA recorded the lowest expense after Skye Bank, which positioned the bank as the 2nd most profitable bank during the 2013 financial year.

\section{Stress test using altman's model}

Altman's (2000) revised model has been applied throughout this test. All seven banks under review are examined to ascertain whether there are any potential failures in these financial institutions (Anjum, S., 2012). Although the stress test may vary, the Total Z-Scores is one of the most simplified models to use and easy to relate information to (Diakomihalis, M., 2012). The result of the stress test shows that Skye Bank came the closest to the 1.24 benchmark. This is due to the huge share capital the bank maintains against its liabilities. Reason for these low Z-Scores is the small capital employed by the banks. With such performances, the banks need to consider listing on the Sierra Leone Stock Exchange so that it can generate more money from a wider shareholder base (Jan, A., \& Marimuthu, M., 2015).

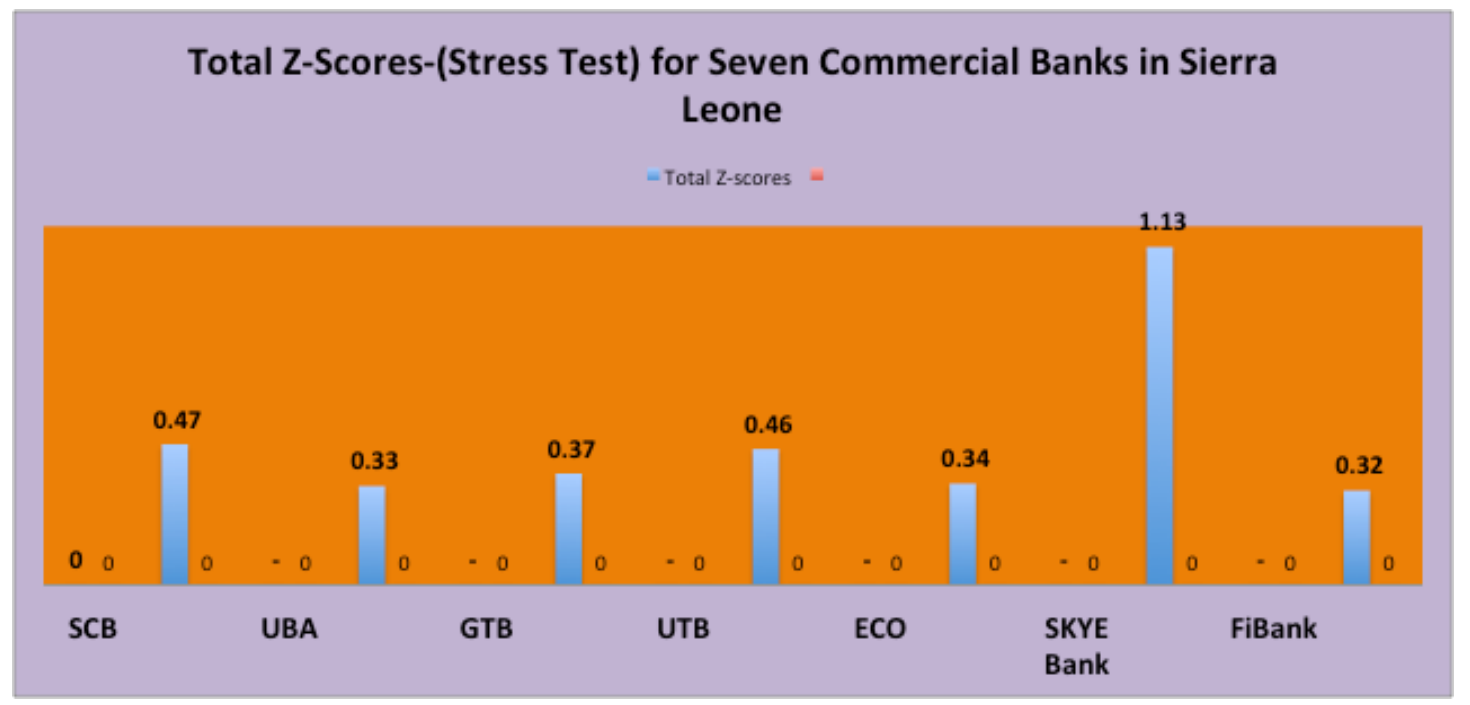

Chart 5. Z-Test scores for banks in sierra leone based on 2013 financial statements

The Central Bank of Sierra Leone's strategy in increasing the bank's share capital by US $\$ 1$ million every year is a laudable approach. However, from the Z-Score results, domestic banks could benefit further if this annual increment is raised to US\$1 million.

This will ensure efficient liquidity and capital requirements in order to safeguard and protect domestic banks from systemic risks. Skye Bank would have been the only bank to pass the stress 
test provided that its retained profit was positive. Skye Bank has the largest share capital of all the banks under review.

\section{Return on capital employed}

All the banks under review posted an impressive return on capital employed. GTB was the most profitable financial institution in 2013, with 69\% ROCE. In second place was UBA.

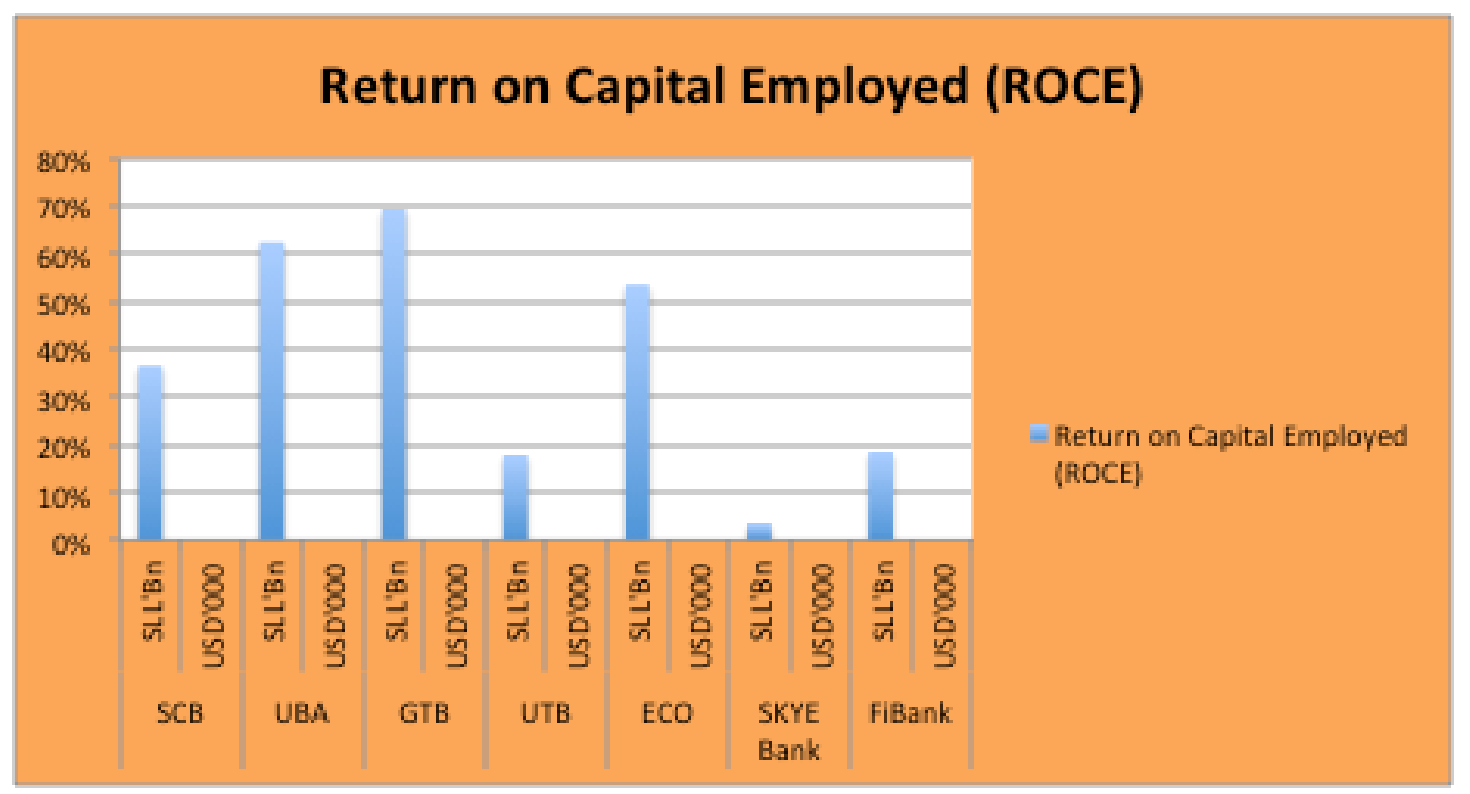

Chart 6. Return on capital employed for retail banks in sierra leone 2013

The bank's management managed its administrative expenditure to declare an active profit position. If GTB, ECO and SCB had done the same, these banks would have published outstanding results for its shareholders.

FIB and UTB were also quite profitable with each recording 18\% ROCE, which gave them a leading edge in attracting investment opportunities. Although these banks scored low on the stress test, they proved to be quite profitable, confirming that if they were well capitalised, these banks would have passed the stress test with ease and thus place them on par with international banks. Based on the results, it would appear 2013 was an active performing year for these seven banks and a real turnaround for their future challenges.

\section{International financial reporting standards (IFRS)}

In Sierra Leone the conceptual frameworks that were previously applied to present financial statement were the SSAP (Statement of Standard Accounting Practice), ad-hoc standards and the GAAP (General Accepted Accounting Practice). The difference between the GAAP and the IAS/IFRS is that the GAAP is a dynamic concept that changes constantly as new local legislations are introduced into the system. A legislation may be relevant to only one country, in this case, if a multilateral company applies the GAAP standards and practice, it will be difficult to harmonize the financial reports simply because one country may apply a national legislation that may not be in line with other countries.

The IAS/IFRS standards however is rigid and comprehensive and designed to suit national legislations, regulators, business communities, academics, interested individuals and organization that require such financial statements. The IAS/IFRS encompasses every aspect of financial reporting that is acceptable to all jurisdictions, even though some countries prefer to apply their own standards. Notwithstanding the above, the IFRS/IAS is a globally accepted as a standard that meets a level playing field for the applicable countries tax systems and the firms they regulate. If a firm applies GAAP to produce its financial statements these may not be accepted in the international arena, where IAS/IFRS standards are the regulatory requirements. This is the reason 
Sierra Leone has embraced and instituted the application of the IAS/IFRS that is now widely adopted by a majority of domestic firms.

The IFRS framework brings consistency to Sierra Leone's reporting system and enhances the level playing field for its smooth application; for instance, when Sierra Leone was adopting the GAAP framework, inventory valuation was stated by using the FIFO (first in first out) rule, whilst in the USA, this was done using the LIFO (last in first out) rule. Under the IFRS framework the standard was revised to IAS 2, it outlines that the inventory valuation "recognized the use of FIFO or the weighted average method for ordinarily interchangeable inventory items". Another instance is the treatment of development expenditure; the Sierra Leone GAAP writes off its development expenditure over a period, or within the same year, except if such development expenditure is deferred. Whilst in the USA, the development expenditure is written off into the profit and loss under all circumstances. Under IAS38, development expenditure is capitalized provided certain criteria are met.

\section{Analysis and comments}

Skye bank scored just below the critical 1.24 benchmark with UTB and Standard Chartered almost neck on the neck for the second position. Since the global financial crisis that occurred over the past few years, new measures by Central Banks and policymakers are ensuring that banks are adequately capitalised, this step ensures that potential defaults can be identified quite early and the risk of collapse averted. The Z-score formula is used to predict whether a firm will go into bankruptcy within two years based on some variables. In simulations and test the Altman $Z$-Score was found to be $72 \%$ accurate in predicting bankruptcy two years before the event.

Shareholders and management of GTB and UBA and ECO must be quite pleased with such performing result regarding Return On Capital Employed (ROCE). Shareholders often evaluate Manager's performance regarding the company's overall return on capital employed; these points are relatively insignificant when compared to two further difficulties. The first concerns are the accounting profit rather than cash flow is used as the basis for evaluation. This is an entirely incorrect concept to use in a decision-making context. Accounting profit is a reporting concept; it is a creation by accountants. A capital investment decision is an economic or resource allocation decision, and the economic unit of account is cash because it is money that gives power over resources. The other criticism of ROCE is that it also ignores the time value of money

\section{Conclusion}

The above listed banks under review must start planning and organizing well-managed liquidity in their various banks and considering participating in generating more share capital through the Sierra Leone Stock Exchange. It is also advisable for the banks to diversify their assets into various trading and stop holding too much cash in hand in order to maximise their shareholders fund. On a whole, the 2013 were a performing period for these seven banks and a good turn around for their future challenges. Although the 2014-year was a worse year for the country and as the deadly Ebola virus destroy most of the gains these banks achieved. However, this is a lesson to take note of as good financial practice will help an institution to stand out during financial stress. Hence, the theme for this conference, hinge on Global Education, Research and Technology for Sustainable Development.

\section{Reference}

[1].Anjum, S., (2012), 'Business bankruptcy prediction models: A significant study of the Altman's Z-score model', Asian Journal of Management Research, ISSN 2229-3795, http://www.ipublishing.co.in/ajmrvol1no1/volthree/EIJMRS3018.pdf.

[2].Banerjee, R., N., and Mio, H. (2014), 'BIS Working Papers No 470: The Impact of Liquidity Regulation on Banks', Monetary and Economic Department, JEL Classification: E32, E51, F30, G21, G28 http://www.bis.org/publ/work470.pdf. 
[3].Diakomihalis, M., (2012), ' The accuracy of Altman's models in predicting hotel bankruptcy', International of Accounting and Financial Reporting, ISSN 2162-3082 2012, Vol. 2, No. 2.

[4].International Financial Reporting Standards: http://www.ifrs.org/issued-standards/list-of-standards/

[5].Jan, A., \& Marimuthu, M., (2015),' Altman Model and Bankruptcy Profile of Islamic Banking Industry: Comparative Analysis on Financial Performance', International Journal of Business and Management; Vol. 10, No. 7, 2015, ISSN 1833-3850 E-1833-8119.

[6].Khan and Singhal, 2015, 'Growth and Profitability Analysis of Selected IT Company', IRACTInternational Journal of Commerce, Business and Management (IJCBM), ISSN: 2319-2828, Vol. 4, No3, June 2015.

[7].Sierra Leone Companies Act 2009, http://www.sierra-leone.org/Laws/2009-05.pdf.

[8].Sthapit, A., \& Maharjan, G. (2012). 'Impact of Liquidity management on profitability: A comparative study of foreign joint-venture banks in Nepal. Lumbini Journal of Business and Economics (ISSN: 20911467), 2(2), 59-72.

[9].Tulsian, (2014), 'Profitability Analysis (A Comparative study of SAIL \& TATA Steel)', Journal of Economics and Finance (IOSR-JEF). e-ISSN: 2321-5933, p-ISSN:2321-5925, volume3, Issue 2, Ver. 1 (Mar-Apr 2014), PP 19-22 www.iosrjournals.org.

[10]. Venkatesan, T., and Nagarajan, S., K., (2012), 'An Empirical Study of Profitability Analysis of Selected Steel Companies in India', International Journal of Marketing, Financial Services \& Management Research, Vol. 1 Issue 10, October 2012, ISSN 22773622.

[11]. Vintila, G., and Nenu, E., A., (2016), 'Liquidity and Profitability Analysis on the Romanian Listed Company', Journal of Eastern Europe Research in Business and Economics, Vol. 2016(2016) Article ID 161707, 8 pages, DOI: 10.5171/2016.161707.

7 Banks published financial statements are annexed below for further analysis.

\begin{tabular}{|c|c|c|c|c|c|c|c|}
\hline & USD'000 & USD'000 & USD'000 & USD'000 & USD'000 & USD'000 & USD'000 \\
\hline Interest income & 9,555 & 3,572 & 10,214 & 8,167 & 10,533 & 864 & 6,961 \\
\hline Interest expenses & -978 & -546 & $\begin{array}{r}-2,434 \\
-\end{array}$ & $\begin{array}{r}-1,683 \\
-\end{array}$ & $\begin{array}{r}-3,799 \\
-\end{array}$ & -159 & $\begin{array}{r}-3,003 \\
-\end{array}$ \\
\hline Net interest income & 8,576 & 3,026 & $\mathbf{7 , 7 8 0}$ & 6,483 & 6,734 & 705 & 3,958 \\
\hline $\begin{array}{l}\text { Fees and commission } \\
\text { income }\end{array}$ & 2,571 & 1,774 & 5,255 & 2,389 & 3,890 & 341 & 1,706 \\
\hline Net trading income & 2,161 & - & 2,343 & 523 & 2,662 & 227 & 2,138 \\
\hline $\begin{array}{l}\text { Other operatıng } \\
\text { income }\end{array}$ & $\begin{array}{l}- \\
-\end{array}$ & 1,297 & $\begin{array}{l}- \\
-\end{array}$ & $\begin{array}{l}- \\
-\end{array}$ & 159 & & \\
\hline Revenue & 13,308 & 6,097 & 15,378 & 9,395 & 13,445 & 1,274 & 7,803 \\
\hline $\begin{array}{l}\text { Net impairment loss } \\
\text { on loans and }\end{array}$ & & - & - & & - & & \\
\hline Advances & 23 & - & $-1,410$ & $-1,570$ & $-1,501$ & 136 & -546 \\
\hline Personnel Expenses & $-3,208$ & - & $-2,207$ & - & $-2,252$ & $-1,297$ & $-2,389$ \\
\hline Depreciation & -523 & - & $-1,092$ & - & -910 & - & -819 \\
\hline $\begin{array}{l}\text { Operating Lease } \\
\text { expense }\end{array}$ & - & - & -159 & - & -273 & - & 0 \\
\hline Other Expenses & $-6,984$ & - & $-5,551$ & - & $-5,846$ & - & $-3,321$ \\
\hline Operating Expenses & - & $-3,367$ & - & $-6,233$ & - & - & \\
\hline $\begin{array}{l}\text { Profit before income } \\
\text { tax }\end{array}$ & 2,616 & 2,730 & 4,959 & 1,592 & 2,662 & 114 & 728 \\
\hline Income tax expense & -773 & -796 & $-1,592$ & -478 & -933 & -23 & -205 \\
\hline
\end{tabular}




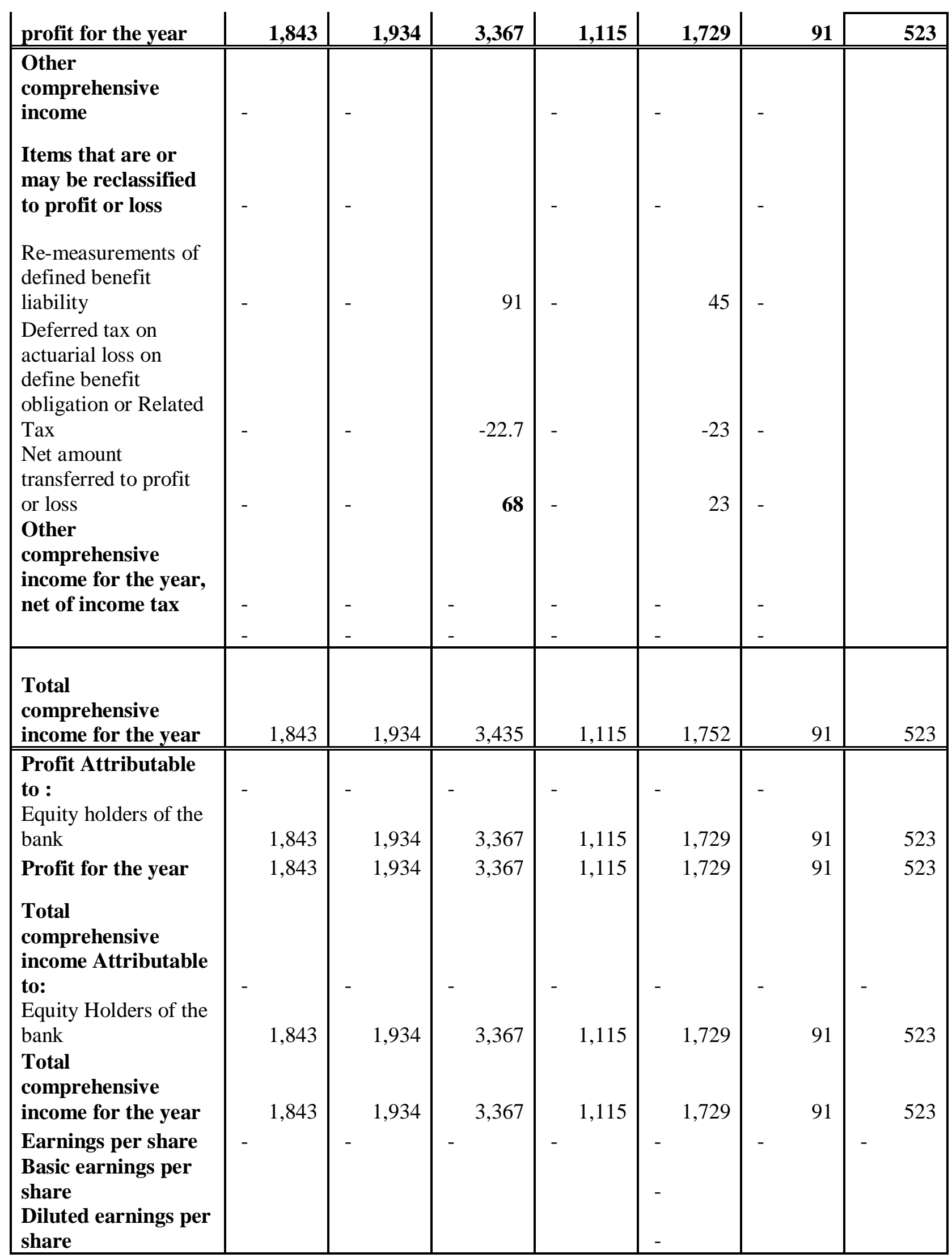

